Herlita Tan, H.H Daniel Tamburian: Pola Komunikasi Suami Istri Berbeda Agama dalam Membangun Keharmonisan

\title{
Pola Komunikasi Suami Istri Berbeda Agama dalam Membangun Keharmonisan
}

\author{
Herlita Tan, H.H Daniel Tamburian \\ herlita21@yahoo.com, danielt@fikom.untar.ac.id
}

Fakultas Ilmu Komunikasi Universitas Tarumanagara

\begin{abstract}
Communication is one of crutial aspect in human life. When done right, communication certainly make relationship grows better and in harmony. In many occation, miscommunication happen when there is a failure in delivering messages to the interlocutor. Hence, the miscommunication could cause problem to married couple. Successful marriage is created when husband and wife could communicate well while holding on their religius value. Nonetheless, there always families which is not living in harmony. Therefore, the purpose of this thesis is to analyse marriage couple communication pattern, especially in different religion to create a happy family. This study uses qualitative approaches with descriptive research method. Researches interviewed 6 resource which consist of a married husband and have a different religious but still harmonized. The result of this study showed that husband and wife who had lived up many years and there is an attitude that relented and understanding of each other, as well as a variety way to maintain it.
\end{abstract}

Keywords: communication patterns, family harmony, married couples

\begin{abstract}
Abstrak
Komunikasi merupakan salah satu aspek penting dalam kehidupan manusia. Komunikasi yang benar tentunya dapat membuat hubungan menjadi lebih baik dan harmonis. Sebaliknya kesalahpahaman dalam komunikasi bisa menimbulkan masalah yang serius. Seringkali dalam proses komunikasi terdapat kegagalan dalam penyampaian pesan kepada lawan bicaranya. Hal ini dapat menimbulkan permasalahan khususnya bagi pasangan suami istri yang sudah menikah. Keharmonisan suami istri terjadi hanya jika mereka dapat berkomunikasi dengan baik dan tetap berpegang teguh kepada nilai-nilai agama yang dianut. Namun tidak dapat dipungkiri bahwa di dalam tatanan rumah tangga menjadi tidak harmonis yaitu salah satunya adalah perbedaan agama pada suami istri. Maka dari itu penelitian ini ingin mengetahui pola komunikasi suami istri berbeda agama dalam membangun keharmonisan. Penelitian ini menggunakan pendekatan penelitian kualitatif dengan metode deskriptif. Pada penelitian ini peneliti mewawancarai enam narasumber yang terdiri dari pasangan suami istri yang sudah menikah dan memiliki perbedaan agama namun masih tetap harmonis. Hasil penelitian lewat kajian pola komunikasi suami istri ini memperlihatkan bahwa pasangan suami istri yang telah menjalani kehidupan rumah tangganya bertahuntahun terdapat sikap saling mengalah dan pengertian antara satu sama lain, serta memiliki cara-cara yang beragam untuk tetap mempertahankannya.
\end{abstract}

Kata Kunci: keharmonisan keluarga, pasangan suami istri, pola komunikasi

\section{Pendahuluan}

Keluarga terdiri dari hubungan sukarela yang penuh ikatan emosional, nasihat serta cerita tentang kebahagiaan maupun kesedihan. Seperti yang dikutip dari jurnal 
milik Novianti, Sondakh, dan Rembang (2017) yaitu keluarga merupakan salah satu pusat kebahagiaan, dan pada dasarnya setiap keluarga ingin membangun sebuah keluarga yang bahagia dan penuh dengan rasa saling mencintai satu dengan yang lainnya secara bersama-sama. Namun tidak bisa dipungkiri banyak sekali keluarga yang mengalami ketidakharmonisan dikarenakan dengan adanya perbedaan agama satu sama lain. Walaupun tidak selalu demikian namun ketika ditemukan adanya perbedaan agama, keluarga menjadi tidak harmonis jika dibandingkan dengan keluarga seiman lainnya.

Beberapa pengalaman juga menunjukkan hubungan antara agama dengan perkawinan membawa banyak sekali konflik dalam rumah tangga. Realita tersebut menunjukkan adanya konsepsi yang kompleks dari keluarga dan realita yang berdampak pada pola komunikasi yang diterapkan. Komunikasi merupakan salah satu faktor penting di dalam kehidupan manusia, seperti yang dikutip dari jurnal yang bernama Hadawiah (2018) bahwa sepanjang masa hidupnya manusia selalu berkomunikasi, terlebih ketika menjalin suatu hubungan. Di dalam sebuah keluarga pasti memiliki pola komunikasi yang selalu diterapkan setiap hari terus-menerus, termasuk dalam keharmonisan sebuah keluarga yang berbeda agama.

Pada saat ini kasus yang banyak terjadi di masyarakat yaitu banyak terjadi perkawinan dengan latar belakang perbedaan agama. Walaupun banyak fakta yang menunjukkan bahwa keharmonisan dalam keluarga beda agama tidaklah mudah, namun penulis ingin mengetahuinya secara langsung dan akan berusaha menjawab problematika tersebut. Melihat keadaan realita yang ada, maka membuat penulis menjadi tertarik untuk meneliti fenomena ini dengan berfokus pada bagaimana pola komunikasi suami istri berbeda agama dalam membangun keharmonisan. Adapun tujuan yang ingin dicapai peneliti dalam penelitian ini adalah untuk menganalisis pola komunikasi yang ada di dalam keluarga mereka.

\section{Metode Penelitian}

Pada penelitian ini, peneliti menggunakan metode penelitian pendekatan kualitatif. Peneliti memilih metode kualitatif ini dikarenakan fenomena yang ingin diteliti yaitu pola komunikasi suami istri berbeda agama dalam membangun keharmonisan. Menurut Denzin \& Lincoln (1994) dalam Albi \& Setiawan (2018), metode penelitian kualitatif adalah penelitian dengan maksud menjelaskan fenomena yang ada dengan berbagai macam metode.

Secara umum, metode penelitian kualitatif mempunyai makna yaitu metode yang lebih menekankan pada nilai-nilai pemahaman secara mendalam terhadap suatu masalah. Penelitian kualitatif juga bertujuan untuk menggali dan memahami secara mendalam suatu yang tersembunyi atau tidak terlihat dibalik fenomena yang ada.

Metode penelitian yang penulis gunakan untuk penelitian ini yaitu metode penelitian deskriptif kualitatif. Penulis menggunakan ini karena penulis ingin mengetahui tentang fenomena yang ada dan untuk mendeskripsikan data yang telah peneliti peroleh sebagai hasil suatu penelitian.

Adapun teknik pengumpulan data yang digunakan untuk penelitian ini yaitu penulis menggunakan beberapa metode pengumpulan data seperti pengamatan secara langsung (observasion), wawancara (interview), dan dokumentasi (documentary). Narasumber yang peneliti gunakan sebagai subjek penelitian yaitu ada 6 narasumber yang masing-masing terdiri dari dua pasang pasangan suami istri yang sudah menikah diatas 20 tahun tetapi masih memiliki keluarga yang harmonis. 
Herlita Tan, H.H Daniel Tamburian: Pola Komunikasi Suami Istri Berbeda Agama dalam Membangun Keharmonisan

\section{Hasil Temuan dan Diskusi}

Dalam penelitian ini, peneliti mewawancarai 6 narasumber yaitu narasumber pertama pasangan Bapak Eddy dan Ibu Lina, narasumber kedua pasangan Bapak Hendra dan Ibu Iryani, pasangan ketiga Bapak X dan Ibu Y. Dalam penelitian ini penulis dapat memberikan tanggapan bahwa pola komunikasi yang baik dalam hubungan suami istri yaitu harus saling memberikan dukungan satu sama lain, mencari solusi bersama-sama dalam memecahkan titik permasalahan dan tidak selalu egois serta yang paling penting selalu memberikan toleransi antara kedua agama untuk bertukar pandangan dan pendapat. Pola komunikasi yang berdampak pada kehidupan suami istri yaitu pola komunikasi persamaan karena jika pasangan suami istri menerapkan pola komunikasi persamaan maka tidak ada pemaksaan, melainkan memiliki kesetaraan di dalam menjalani hubungannya.

\section{Keluarga dan Agama}

Agama mempunyai peran sangat penting dalam mendidik tumbuh kembang anak, agama selalu mengajarkan hal-hal baik kepada siapapun, entah agama apapun yang dianut pasti di dalamnya terkandung nilai-nilai agama yang bisa diterapkan dalam kehidupan sehari-hari. Keluarga erat kaitannya di dalam agama, karena ketika sepasang suami istri yang sudah memiliki anak, pastilah mereka harus bersama-sama menerapkan nilai-nilai agama yang baik agar bisa diikuti oleh anaknya kelak. Suami istri yang menjalankan ibadahnya dengan baik sehingga menciptakan keharmonisan, pasti anak pun akan mencontohkan hal-hal baik dari kedua orangtuanya karena anak menjadi cerminan dari kedua orangtua.

\section{Pola Komunikasi Suami dan Istri}

1. Pola komunikasi merupakan faktor yang harus dikembangkan setiap harinya, terlebih pada hubungan suami istri. Pola komunikasi akan sangat menentukan bagaimana hubungan tersebut akan berjalan lancar dan harmonis ke depannya. Tentunya penerapan dari masing-masing keluarga memiliki pola komunikasi yang berbeda. Hal ini selaras dengan masing-masing karakter dalam mengaplikasikan pola komunikasi di dalam keluarga mereka. Seperti pada pasangan Bapak Eddy dan Ibu Lina, ketika penulis tanyakan perihal pola komunikasi yang terjadi saat ini, ia menjawab bahwa mereka berkomunikasi selalu saling berbagi, tidak ada keegoisan, dan dalam menyelesaikan masalah pun dengan sikap saling pengertian di dalam hubungannya. Hal ini selaras dengan terapan dari pola komunikasi persamaan yang dikutip dari buku DeVito, Joseph A., (2009) berjudul The Interpersonal Communication Book yang digunakan dalam hubungan keluarga Bapak Eddy dan Ibu Lina. Maka dari itu, penulis melihat bahwa adanya sikap saling menghormati antara pasangan ini, walaupun terjadi pertengkaran atau konflik namun tidak menjadi ancaman bagi kedua pasangan ini.

2. Dalam membangun hubungan, pasangan kedua yaitu pasangan Bapak Hendra dan Ibu Iryani menerapkan pola komunikasi seimbang terpisah di mana baik suami maupun istri sama-sama saling memegang kontrol atau kekuasaan di bidangnya namun konflik tidak dianggap sebagai ancaman karena masing-masing memiliki wilayahnya sendiri yaitu Bapak Hendra di bidang wirausaha (mencari nafkah) sedangkan Ibu Iryani di bidang rumah tangga, jika terjadi konflik tentang pekerjaan rumah sudah pasti yang memenangkan komunikasi yaitu Ibu Iryani 
karena Ibu Iryani yang memahami kondisi yang terjadi dalam pekerjaan rumah tangga.

3. Komunikasi yang terjadi antara informan yang ketiga yaitu Bapak X dan Ibu Y, dalam membangun hubungan yang baik, pola komunikasi yang diterapkan Bapak $\mathrm{X}$ dan Ibu Y yaitu pola komunikasi persamaan, mereka sama-sama berkomunikasi secara terbuka dalam menyampaikan pendapat masing-masing tanpa adanya pihak yang dominan dengan ditandainya oleh hubungan timbal balik. Hal ini selaras dengan kutipan jurnal dari Lisbon Pangaribuan (2016). Walaupun Ibu Y tidak bekerja, namun Bapak X menghormati Ibu Y sebagai mana semestinya, tidak ada yang menggangap masing-masing benar, ketika ada kesalahan pun masing-masing saling untuk intropeksi diri. Hal ini yang membuat hubungan Bapak X dan Ibu Y tetap harmonis.

\section{Komunikasi Interpersonal yang Diterapkan untuk Membangun Keharmonisan}

Adapun komunikasi interpersonal yang diterapkan untuk membangun keharmonisan di tengah kondisi banyaknya perceraian pada pasangan, Bapak Eddy dan Ibu Lina mengatakan bahwa apa yang sudah dimulai harus bisa dipertanggungjawabkan. Bapak Eddy dan Ibu Lina membentuk pola komunikasi interpersonal yang dikutip dari buku DeVito, Joseph A., (1997) berjudul komunikasi antar manusia, yang selalu memiliki keterbukaan serta memiliki dukungan satu sama lain, walaupun memiliki perbedaan agama namun mereka yakin bahwa mereka memang sudah dipertemukan untuk menjadi satu pasang. Maka dari itu, dalam keluarga Bapak Eddy dan Ibu Lina tetap mendukung satu sama lain, baik agama hingga hal yang lain, dan juga selalu memiliki keterbukaan dalam hal komunikasi mereka.

Pasangan kedua yaitu Bapak Hendra dan Ibu Iryani meyakini bahwa ketika berkomunikasi, salah satu dari masing-masing harus dalam keadaan hati yang tenang atau harus menciptakan rasa positif terlebih dahulu di dalam diri. Hal ini karena apabila mereka sedang dalam kondisi kepala yang panas maka sangat rentan untuk bertengkar. Kedua pasangan sama-sama memiliki sifat cuek dan keras kepala. Namun ketika sedang terjadi permasalahan mereka lebih memilih mengambil titik tengah dari keputusan-keputusan yang mereka buat.

Hubungan komunikasi yang tetap terjalin tentu juga memiliki dampak yang baik kepada anak, seperti pada pasangan Bapak X dan Ibu Y yang memiliki komunikasi interpersonal cukup baik. Keduanya memiliki keterbukaan dalam hal apapun serta memiliki kesetaraan di dalam rumah tangga, tidak ada yang merasa hebat satu sama lain melainkan setara. Bahkan hal paling penting yang harus diterapkan di dalam hubungan dari penuturan Bapak $X$ yaitu adanya rasa saling menghargai, berguna serta adanya pujian setiap harinya, agar pasangan merasa tetap disayang dan juga anak dapat melihat tersebut dari kedua orangtuanya.

\section{Pendukung dan Penghambat Keharmonisan Keluarga}

1. Dalam menjalankan suatu rumah tangga tidak selalu mulus, pasti ada kerikilkerikil kecil maupun besar di dalam rumah tangga. Kerikil-kericil tersebut bisa membawa hubungan semakin langgeng atau pun semakin rusak seperti yang dikutip dari jurnal yang bernama Hardsen Julsy Imanuel Najoan (2015), dan tergantung dari sikap yang dijalani masing-masing keluarga. Hal ini selaras dengan jawaban dari pasangan Bapak Eddy dan Ibu Lina, mereka mengatakan bahwa menikah itu bukan untuk senang-senang saja namun untuk menjadi satu, 
yang terkadang itu menimbulkan suatu konflik. Faktor pendukung yang dilakukan di dalam keluarga ini yaitu Bapak Eddy dan Ibu Lina seperti berpacaran atau berbulan madu lagi kembali walaupun sudah memiliki anak-anak. Keduanya memberikan waktu khusus (quality time) dalam hubungan mereka baik itu quality time berdua saja ataupun bersama anak-anak. Namun di samping faktor pendukung, ada juga faktor-faktor yang membuat hubungan mereka merasa seperti diguncang, yaitu karena semakin mendominasinya era teknologi sekarang, yang membuat seakan-akan manusia tidak bisa lepas dari gadget dalam waktu yang lama. Faktor tersebut mungkin merupakan hal yang sepele namun jika tidak diselesaikan akan menimbulkan pertengkaran. Pada era ini, komunikasi tatap muka sudah digantikan dengan komunikasi melalui telepon. Kondisi ini kedepannya akan membuat hubungan menjadi kurang dalam berkomunikasi.

2. Hubungan harmonis memang dambaan semua keluarga, akan tetapi terkadang sering timbul konflik dan hambatan yang menghambat seperti pada pasangan Bapak Hendra dan Ibu Iryani, yaitu hambatan ketika masing-masing tidak diberikan izin untuk melakukan apa yang pasangan sukai dan tidak bisa melakukan sesuatu hal jika salah satu pasangan tidak menyukainya. Misalnya pada saat Ibu Iryani berpergian, ia lebih suka berpergian sendiri dan bersama teman-temannya.

3. Terakhir, pasangan Bapak X dan Ibu Y memiliki faktor pendukung yaitu selalu mempertahankan pernikahan mereka dengan komitmen pada saat awal janji pernikahan. Hal ini membuat mereka selalu merasa ada dukungan satu sama lain ketika bertengkar. Namun ada juga faktor-faktor yang menghambat keduanya yaitu ketika apa yang disukai Ibu Y tidak disukai oleh Bapak X, begitu juga sebaliknya.

\section{Simpulan}

Penelitian mengenai pola komunikasi suami istri berbeda agama dalam membangun keharmonisan dapat disimpulkan bahwa:

a) Kehidupan berumah tangga itu tergantung dari cara berkomunikasi dan cara penyampaian pesan yang diberikan. Pasangan suami dan istri menggunakan beberapa cara untuk berkomunikasi dan menyelesaikan masalah yaitu menggunakan komunikasi tatap muka secara langsung atau komunikasi interpersonal.

b) Pola komunikasi yang terdapat pada pasangan suami istri meliputi dua pola komunikasi yang berbeda-beda yaitu menggunakan pola komunikasi persamaan dan pola komunikasi seimbang terpisah yang dikutip dari buku DeVito, Joseph A., (2009) berjudul The Interpersonal Communication Book. Pola komunikasi yang paling efektif digunakan yaitu pola komunikasi persamaan dimana peran suami dan istri sama dalam semua hal, tidak ada yang saling mendominasi

c) Faktor yang menghambat pasangan suami istri adalah ketika masing-masing suami ataupun istri memiliki sudut pandang yang berbeda dan tidak sama.

d) Saran untuk semua pasangan suami istri agar selalu memberi dukungan dan motivasi kepada masing-masing pasangan apapun yang ia lakukan dan yang terpenting adalah untuk terus menjaga komitmen yang sudah disepakati dari awal ketika menjalin sebuah hubungan sebagai sebuah pasangan suami istri

Saran dari penelitian ini adalah apabila ada peneliti lain yang akan mengambil topik serupa maka dapat melihat dari sisi orang lain yang berhubungan 
dekat dengan pasangan suami istri untuk mengetahui apakah benar komunikasi tersebuut diterapkan di dalam hubungan atau tidak. Kemudian peneliti menyarankan untuk mengkaji lebih banyak sumber dan referensi yang lebih mendalam terkait topik tersebut.

\section{Ucapan Terima Kasih}

Peneliti ingin menyampaikan terima kasih kepada Fakultas Ilmu Komunikasi Tarumanagara, pembimbing, para narasumber, orang tua, dan teman-teman yang telah memberikan dukungan sehingga penelitian ini dapat terselesaikan dengan baik.

\section{Daftar Pustaka}

Anggito, Albi., \& Setiawan, Johan. (2018). Metode penelitian kualitatif. Propinsi Sukabumi: Penerbit CV Jejak.

DeVito, Joseph A. (1997). Komunikasi Antar Manusia, Edisi Kelima. Jakarta: Professional Books.

DeVito, Joseph A., (2009). The Interpersonal Communication Book, Edisi Kesebelas. Jakarta: Professional Books.

Pangaribuan, L. (2016). Kualitas Komunikasi Pasangan Suami Istri Dalam Menjaga Keharmonisan Perkawinan. JURNAL SIMBOLIKA: Research and Learning in Communication Study, 2(1). Diakses di https://ojs.uma.ac.id/index.php/simbolika/article/view/214

Novianti, Riska Dwi., Sondakh, Mariam., Rembang, Meiske. (2017). Komunikasi Antar Pribadi Dalam Menciptakan Harmonisasi (Suami dan Istri) Keluarga Di Desa Sagea Kabupaten Halmahera Tengah. Acta Diurna Komunikasi, 6 (2). Diakses https://ejournal.unsrat.ac.id/index.php/actadiurnakomunikasi/article/view/1620 $3 / 15707$

Najoan, Hardsen Julsy Imanuel. (2015). Pola Komunikasi Suami Istri Dalam Menjaga Keharmonisan Keluarga Di Desa Tondegesan II Kecamatan Kawangkoan Kabupaten Minahasa. Sulawesi. Acta Diurna Komunikasi, 4(4). Diakses https://ejournal.unsrat.ac.id/index.php/actadiurnakomunikasi/article/view/8504 Hadawiah. (2018). Pola Komunikasi Pasangan Suami Istri Beda Budaya Di Makassar. Al-Munzir, 10(2), 228-245. Diakses di https://ejournal.iainkendari.ac.id/al-munzir/article/view/808 